\title{
PROMOSI PERSONAL SELLING SURAT KABAR BOGOR TODAY DALAM MENARIK MINAT PEMASANG IKLAN
}

\section{PROMOTION PERSONAL SELLING LETTER OF BOGOR TODAY INTEREST IN THE INTEREST OF ADVERTISERS}

\author{
N Amalia1a, Sukarelawati ${ }^{2}$, AA Kusumadinata ${ }^{3 b}$ \\ 1,2,3 Jurusan Ilmu Komunikasi, Fakultas Ilmu Sosial dan Ilmu Politik, Universitas Djuanda \\ Jl. Tol Ciawi No.1 Kotak Pos 35 Bogor 16720.
}

a,b Korespondensi :

N Amalia, Email : iyanadiaamalia@yahoo.co.id

AA Kusumadinata, Email : alialamsyahkusumadinata@gmail.com

(Diterima: 16-01-2017; Ditelaah: 27-2-2017; Disetujui: 29-03-2017)

\begin{abstract}
This study focused on the promotion of personal selling Bogor Today newspaper in the interest of consumers for advertising. The research objective was to determine the promotion of personal selling Bogor Today newspaper in attracting advertisers. This type of research is qualitative approach using the technique of in-depth interviews or Depth interview. The research shows the newspaper Bogor Today feasilble in the promotion of personal selling seen from the test results analysis SWOT with analisis calculations matric space tend to be good, with the support of the process of marketing communication promotion personal selling, persuasive comunication, with the aim to generate interest from consumers that results.
\end{abstract}

Keywords : promotion, personal selling, interest advertisers.

\begin{abstract}
ABSTRAK
Penelitian ini memusatkan perhatian pada promosi penjualan langsung surat kabar Bogor Today dalam menarik minat konsumen untuk memasang iklan. Tujuan penelitian adalah untuk mengetahui promosi personal selling surat kabar Bogor Today dalam menarik minat pemasang iklan. Jenis penelitian yang digunakan adalah kualitatif dengan menggunakan teknik pendekatan wawancara mendalam atau Depth interview. Hasil penelitian menunjukan surat kabar Bogor Today layak dalam melakukan promosi personal selling dilihat hasil uji Analisis SWOT bahwa dengan perhitungan Analisis matrik space cenderung baik, dengan didukung proses komunikasi pemasaran, promosi personal selling, Komunikasi persiasif, dengan tujuan untuk menimbulkan minat dari konsumen.
\end{abstract}

Kata Kunci : promosi, penjualan langsung, minat pemasang iklan

N Amalia, Sukarelawati, AA Kusumadinata. 2017. Promosi Personal Selling Surat Kabar Bogor Today Dalam Menarik Minat Pemasang Iklan. . Jurnal Komunikatio 3(1): 9-20. 


\section{PENDAHULUAN}

Komunikasi pemasaran pada saat ini memegang peranan yang sangat penting bagi eksistensi sebuah perusahaan. Tanpa komunikasi, konsumen maupun masyarakat secara keseluruhan tidak akan mengetahui keberadaan produk di pasar. Komunikasi pemasaran merupakan sarana yang digunakan perusahaan-perusahaan dalam upaya untuk menginformasikan, membujuk, dan mengingatkan konsumen secara langsung atau secara tidak langsung tentang produk dan merk yang mereka jual. Dalam pengertian tertentu, komunikasi pemasaran menggambarkan suara dan merupakan sarana yang dapat digunakan untuk membangun dialog dan membangun hubungan dengan konsumen.

Dalam setiap kegiatan pemasaran, elemen yang sangat penting adalah komunikasi. Dengan komunikasi kegiatan pemasaran akan berlangsung. Pada tingkatan dasarnya, komunikasi dapat menginformasikan dan membuat konsumen akan menyadari produk/jasa yang ditawarkan. Konsumen akan tertarik dan langkah selanjutnya adalah proses yang diinginkan yaitu pembelian.

Komunikasi juga dapat dijadikan sebagai pengingat bagi konsumen mengenai keberadaan produk/jasanya di masa lalu yang pernah dilakukan. Seiring dengan perkembangan zaman, kini komunikasi pemasaran lebih dikenal dengan komunikasi pemasaran terpadu, yang artinya suatu konsep perencanaan komprehensif yang mengevaluasi peranan dan starategi dari berbagai disiplin komunikasi, misalnya iklan media elektronik personal selling.

$\begin{array}{rrr} & \text { Komunikasi } & \text { pemasaran adalah } \\ \text { elemen dalam } & \text { pemasaran yang }\end{array}$
memberikan arti dan mengkomunikasikan nilai kepada konsumen dan stakeholder kepada perusahaan Machfoedz (2001). Komunikasi pemasaran mengembangkan kesadaran konsumen terhadap produk/jasa yang dihasilkan perusahaan, sehingga konsumen mengenal produk/jasa yang ditawarkan guna merangsang terjadinya penjualan. Dengan demikian pemasaran berupaya untuk mengikatkan hubungan pertukaran ekonomi antara organisasi dan konsumennya.

Fandy, (2012) Promosi merupakan salah satu faktor penentu keberhasilan program pemasaran. Bagaimanapun berkualitasnya sebuah produk/jasa, bila konsumen belum pernah mendengarnya atau tidak yakin bahwa produk itu akan berguna bagi mereka, maka mereka tidak akan tertarik membelinya. Pada hakikatnya, promosi merupakan elemen bauran pemasaran yang berfokus pada upaya menginformasikan, membujuk, dan mengingatkan kembali kepada konsumen akan merek dan produk perusahaan.

$\begin{array}{llr}\text { Effendy } & \text { (1993) } & \text { Konteks ini } \\ \text { perusahaan } & \text { golongan } & \text { apapun }\end{array}$ membutuhkan promosi untuk mencapai tujuan yang diinginkan, salah satunya adalah perusahaan media yang bergelut dalam bidang jasa surat kabar. Surat kabar adalah lembaran cetak yang menurut laporan yang terjadi di masyarakat dengan ciri-ciri terbit secara priodi, bersifat umum, isinya termasa/aktual, mengenal apa saja diseluruh dunia yang mendukung nilai-nilai untuk diketahui khalayak pembaca. Surat kabar merupakan salah satu media massa masih diminati masyarakat, untuk sekedar membaca atau memasang iklan, terbukti masih banyak perusahaan bahkan rumah tangga berlangganan surat kabar khususnya di wilayah Bogor.

Sebagai surat kabar mempunyai banyak kelebihan yang tidak dimiliki oleh media massa lainya seperti radio, televisi, film, dan internet. Kelebihan yang dimiliki surat kabar adalah berita atau iklan yang dipasang di surat kabar dipandang lebih tahan lama sehingga menguasai waktu bagi pembacanya, ada beberapa kekuatan surat kabar. Menurut Gunawan (2003) dikutip pikiran rakyat yaitu Koran atau surat kabar menjangkau daerah perkotaan sesuai dengan cakupan pasar (nasional, regional, local) umumnya konsumen memandang koran memuat hal-hal aktual atau baru 
yang segera diketahui oleh khalayak pembaca dan mampu bebas memilih pasar mana yang di utamakan. Dalam website www.BogorToday.com bahwa surat kabar Bogor Today bersifat independent pembaca sampai saat ini mencapai 36 ribu Oplah/hari. Peluang tersebut menjadi kesempatan perusahaan jasa surat kabar Bogor Today untuk memasangkan jasa rubrik iklan, dengan pembacanya semua lapisan masyarakat pekerja, wirausaha, mahasiswa, hingga ibu rumah tangga.

Komunikasi pemasaran dengan demikian berupaya menginformasikan atau menerangkan, membujuk, dan mengingatkan kembali pada konsumen akan merek dan produk perusahaan. Surat kabar Bogor Today membuka jasa promosi dengan menjual rubriknya untuk pemasang iklan melalui starategi komunikasi personal selling sebagai komunikasi langsung, baik kepada seseorang ataupun pihak pengguna dengan maksud untuk menciptakan terjadinya transaksi pembelian yang saling mengguntungkan bagi kedua belah pihak.

Hasil wawancara dengan Munjani (2016) Pimpinan Redaksi Bogor Today seles eksekutif bahwa strategi personal selling baik dan mampu manarik para perusahaan untuk memasang iklan di surat kabar Bogor Today, karena dengan melalui tatap muka dan persentasi menarik mampu untuk meyakinkan konsumen. Kekuatan surat kabar Bogor Today dalam melakukan promosi rubrik iklan, dibuktikan adanya peningkatan pemasang iklan di awal tahun 2016 bertambah 10\% hingga, dari tahun sebelumnya hanya sekitar $4 \%$ pasang iklan di Bogor Today. Walaupun naik hanya $6 \%$ dari sebelumnya hal tersebut menggambarkan keberhasilan Bogor Today dalam melakukan promosi rubrik iklan melalui Personal selling.

Pada tulisan ini penulis tertarik untuk mengkaji strategi komunikasi pemasaran sebagai langkah promosi surat kabar Bogor Today yang di dukung dengan pendekatan personal selling tersebut bagaimana proses surat kabar menginformasikan, membujuk dan mengingatkan kembali kepada konsumen akan merek dan produk dalam mencapai misinya agar konsumen tertarik untuk pemasang iklan di surat kabar Bogor Today. Tujuan penelitian ini adalah Mengetahui Pola Promosi Personal Selling surat kabar Bogor Today dalam menarik minat pemasang iklan.

\section{METODE PENELITIAN}

Pendekatan dalam penelitian ini adalah pendekatan kualitatif, dengan menggunakan teknik pendekatan wawancara mendalam atau Depth interview. Artinya dimana responden atau kelompok responden mengkomunikasikan bahan-bahan dan mendorongnya untuk mendiskusikan secara bebas. Penelitian dilakukan di Surat Kabar Bogor Today. Penelitian dilakukan pada bulan Desember 2016 hingga Februari 2017. Data yang digunakan data primer dimana data yang diperoleh secara langsung dari sumber ali (tidak memakai perantara), data primer secara khusus dikumpulkan oleh peneliti untuk menjawab pertanyaan-pertanyaan peneliti. Sedangkan data sekunder diperoleh oleh peneliti secara tidak langsung melalui buku, dokumendokumen, dan kepustakaan. Teknik pengambilan data pada penelitian ini dengan menggunakan wawancara, obsevasi, dan dokumentasi.

Teknik analisis data yang digunakan adalah analisis SWOT sebagai teknik analisis data yang relevan. Analisis SWOT diidentifikasikan sebagai faktor untuk mengetahui secara sistematis komunikasi pemasaran di perusahaan. Analisis ini didasarkan oleh logika yang dapat dimaksimalkan kekuatan dan peluang. Namun secara bersamaaan dapat meminimalkan kelemahan dan ancaman. Dengan analisis SWOT ini perusahaan Bogor Today bisa mengetahui sisi kekuatan (Strength), Peluang (Opportunities) dapat dimaksimalkan secara simultan, kelemahan (Weakness), dan ancaman (Threat) dapat 
diminimalisir agar tidak ada penghalang untuk mencapai tujuan

\section{HASIL DAN PEMBAHASAN}

\section{Kegiatan promosi personal selling surat kabar Bogor Today dalam menarik minat pemasang iklan.}

Penelitian ini sangat berkaitan dengan pelaksanaan Promosi personal selling yang dilakukan oleh Surat Kabar Bogor Today . Personal selling merupakan tolak ukur suatu Perusahaan untuk mencapai tujuannya dalam mencapai hasil promosi. Berdasarkan penelitian pada Surat Kabar Bogor Today Penerapan personal selling sebagai salah satu media komunikasi yang tepat dalam strategi pemasaran perusahaan yang dilakukan dengan tepat sasaran untuk mencapai suatu target yang dipenuhi.Surat Kabar Bogor Today selalu menerapkan kepada personal selling yang merupakan bagian terpenting dalam proses promosi agar selalu fokus terhadap promosi dengan sifatnya mengajak yang sudah ditetapkan sebagai tugas seorang personal selling. Surat Kabar Bogor Today mempunyai langkah-langkah yang dilakukan personal selling untuk menarik minat bagi calon pelanggan, dengan melakukan :

\section{Mencari langganan baru (prospecting)}

Langkah pertama dalam proses promosi Personal Selling pada Surat Kabar Bogor Today adalah mengidentifikasi calon pelanggan dengan menyurvei daerah calon pelanggan yang berpotensial untuk didatangi. Berdasarkan hasil observasi yang dilakukan pada bagian marketing Iklan Surat Kabar Bogor Today Sales Excecutive Iklan sudah dapat melaksanaakan persiapan promosi. Dan menurut hasil wawancara dengan Sales Excecutive Iklan Surat Kabar Bogor Today pada tahap ini Sales marketing iklan mencari peta daerah untuk melakukan persiapan promosi. Dengan menentukan
perusahaan/Instansi mana yang berpotensi untuk dikunjungi .

Berdasarkan hasil observasi hasil wawancara A.M tahun 2016, maka peneliti menganalisis bahwa tenaga promosi dapat menetapkan sasaran kunjungannya langsung dan langsung meneliti sumbersumber data pada saat itu juga sehingga dapat memaksimalkan kinerja tenaga promosi ataupun keefektifan waktu.

\section{Promosi Personal Selling}

Langkah ini tenaga promosi personal selling ini dilakukan melalui pendekatan kepada calon pelanggan dengan berbagai cara yaitu:

Pendekatan yang dilakukan melalui via telepon. Berdasarkan hasil wawancara N.M Biro Humas dan PMB Universitas Djuanda dan observasi bahwa untuk menarik calon pelanggan perlu dilakukan pendekatan terlebih dahulu, pendekatan yang dilakukan beraneka ragam tergantung kesanggupan Sales Excecutive iklan untuk menarik calon pelanggan dengan melakukan pendekatan. Pendekatan dengan via telepon merupakan cara yang dilakukan Harian Bogor Today untuk menelepon kembali pelanggan lama dengan menawarkan pemasangan iklan dengan sifat mengajak. Dan juga pendekatan yang dilakukan tersebut hanya ingin mengetahui apakah calon pelanggan tersebut wajib untuk dilakukakan kunjungan lanjutan. Berdasarkan hasil obeservasi via telepon merupakan pendekatan yang kurang efektif karena waktu penawaran yang terlalu singkat sehingga kurang meyakinkan calon pelanggan.

Sales marketing iklan selalu memperhatikan waktu kunjungan. Berdasarkan hasil penelitian yang dilakukan mengenai waktu kunjungan yang dilakukan surat kabar Bogor Today perusahaan sangat memperhatikan waktu kunjungan terhadap calon pelanggan sehingga waktu-waktu yang luang dapat 
diamanfaatkan dengan kegiatan lain sebagai awal pendekatan pendahuluan. Dengan begitu peneliti dapat menganalisis bahwa dengan selalu memperhatikan waktu kunjungan terhadap calon pelanggan maka dapat memberikan perestasi yang baik kepada Sales Excecutive dan berdampak positif bagi kemajuan perusahaan.

Berdasarkan observasi surat kabar Bogor Today sales marketing mampu meningkatkan kepercayaan bagi calon konsumen akan jasa surat kabar Bogor Today dilihat dari wawancara dengan beberapa konsumen M.S selaku sekretaris perusahaan Citrus Bogor, E.R Ketua Bogor Woman Club, N.M Kepala Biro Promosi dan Humas Universitas Djuanda, W.B.S ketua paguyuban Budi Asih yang telah memutusakan berminat untuk berlangganan pasang iklan mereka mengakui bahwa Bogor Today melakukan kunjungan langsung kepada perusahaan untuk melakukan promosi jasa iklan ataupun membuat kerjasama. Kujungan tersebut bertujuan meyakinkan secara fakta kelebihan dengan menggunakan teknik komunikasi persuasif dari surat kabar Bogor Today seperti pada penjualan surat kabar Bogor Today memiliki oplah sebanyak 36 ribu, hal ini merupakan kelebihan yang mampu menimbulkan tingkat kepercayaan yang tinggi sehingga dapat berminat untuk memakai jasa iklan surat kabar Bogor Today.

\section{Pendekatan (approach)}

Tenaga penjual harus mengetahui cara menemui dan menyapa pembeli untuk memulai hubungan yang baik. Hal ini dilakukan seperti penampilan, tenaga Sales marketing iklan harus berpakaian yang rapih, bersikap sopan dan penuh perhatian terhadap calon pelanggan.

\section{Sales marketing Iklan berpakaian rapi dan sopan}

Berdasarkan observasi yang dilakukan harian Bogor Today mengenakan pakaian yang rapi dan sopan, sehingga pada saat mengunjungi pihak yang akan memasang iklan akan memberi kesan yang baik.

\section{Sales marketing bersikap sopan dan penuh perhatian terhadap pembeli}

Berdasarkan observasi peneliti lakukan pada bagian marketing dan terjun langsung dalam kegiatan personal selling, Sales marketing dituntut harus selalu bersikap sopan terhadap calon pembeli. Dengan demikian peneliti menganalisis bahwa sikap sopan Sales Excecutive iklan sangat diperlukan karena hal ini dapat meningkatkan nama baik perusahaan, kinerja Sales Excecutive semakin lama akan semakin baik dan akan berdampak jangka panjang antara pembeli dan penjual.

\section{Penyajian Promosi oleh Surat Kabar Bogor Today}

Langkah ini Sales Excecutive iklan mengutarakan mengenai penawaran harga pemasangan iklan yang ada di surat kabar Bogor Today:

\section{Presentasi promosi oleh Sales Excecutive iklan dilengkapi dengan brosur}

Berdasarkan hasil wawancara dan observasi langsung perusahaan sangat memperhatikan presentasi yang dilakukan oleh Sales Excecutive iklan, ini terbukti dengan dilengkapi brosur sebagai tambahan prensentasi untuk menawarkan dengan menggunakan teknik komunikasi persuasif yang bersifat mengajak. Dengan begitu peneliti menganalisis bahwa presentasi dengan dilengakpi brosur itu sangat penting yang berguna untuk memudahkan Sales Excecutive dalam menjelaskan dan juga dibaca atau diberikan langsung kepada calon pelanggan.

\section{Sales marketing membawa proposal penawaran iklan dalam presentasi}

Berdasarkan observasi yang peneliti lakukan pada bagian marketing iklan surat Kabar Bogor Today diketahui bahwa dalam 
presentasi kepada calon pemasang iklan, Sales Excecutive iklan membawa proposal penawaran pemasangan iklan. Bedasarkan hasil wawancara, observasi dan konfirmasi kepada pihak perusahan pemasang iklan, faktor faktor yang mempengaruhi di dalam pendapatan iklan sebagai penyusunan strategi promosi personal selling di surat kabar Bogor Today adalah berkaitan dengan keberhasilan surat kabar Bogor Today dalam menguasai penyebaran surat kabar yang cakupannya sampai ke hampir pelosok Kabupaten Bogor.

Bagan 1 Proses promosi personal selling surat kabar Bogor Today kepada konsumen

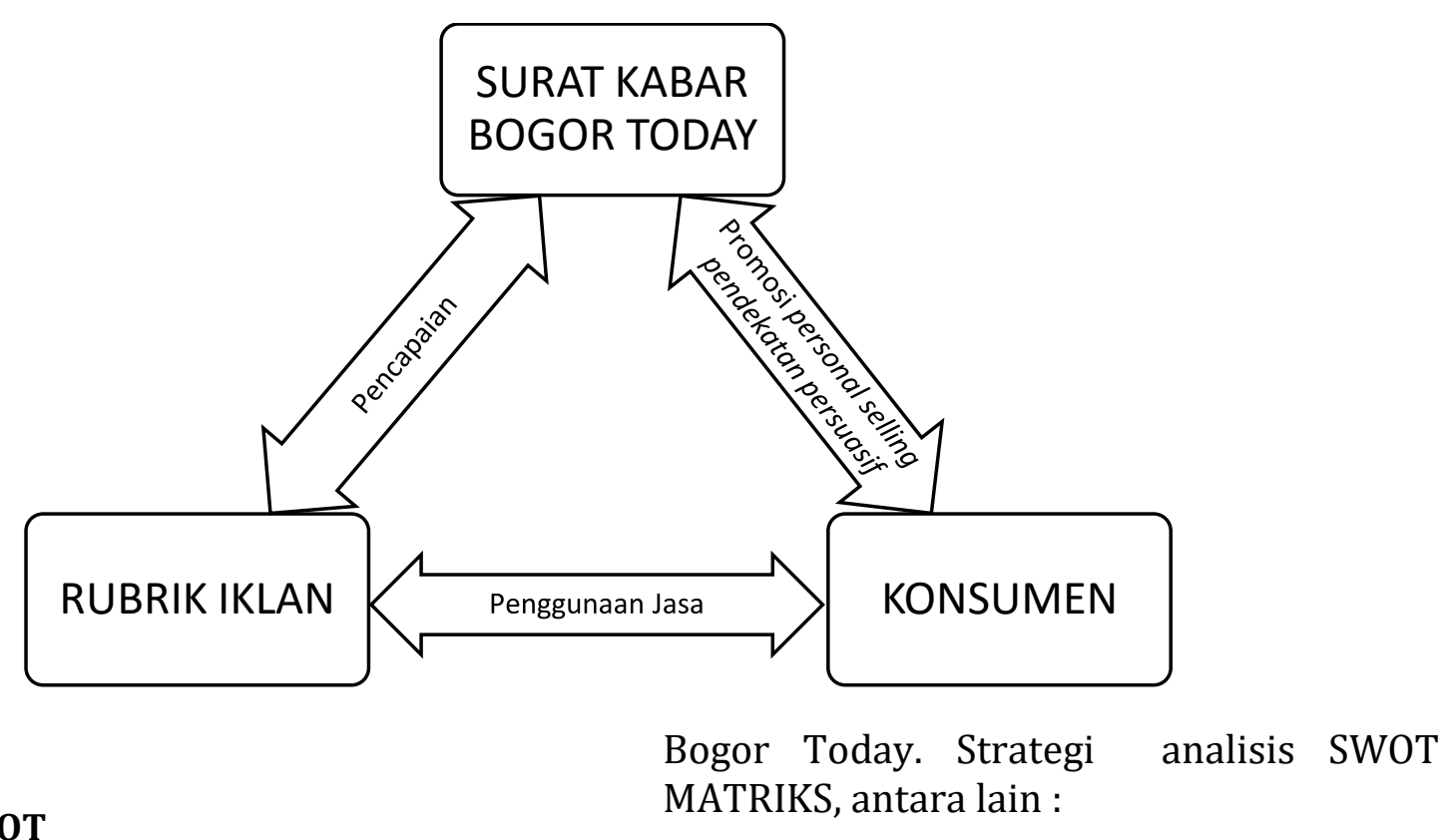

\section{ANALISIS SWOT} MATRIKS, antara lain :

Analisis data yang penulis gunakan dalam penelitian ini adalah dengan analisis SWOT Rangkuti, 2015 Analisis SWOT adalah mengkaji kekuatan, kelemahan, peluang dan ancaman suatu organisasi dengan tujuan untuk mengantisipasi kelemahan dan ancaman yang dimiki surat kabar 
Tabel 1. MATRIX SWOT

\begin{tabular}{|c|c|c|}
\hline Faktor Ekstrenal & 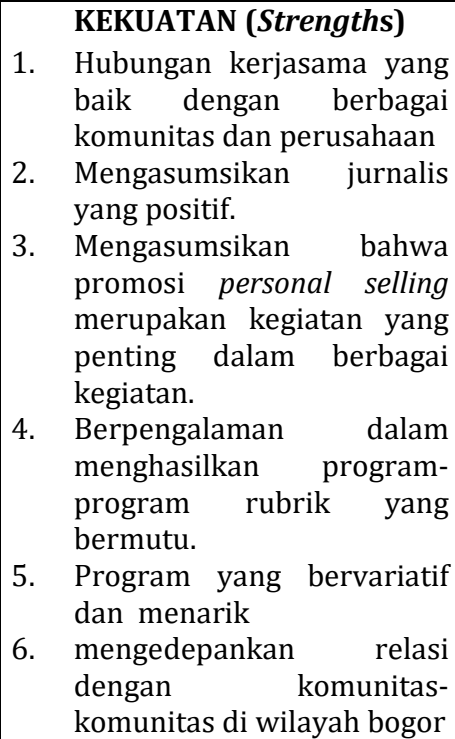 & \begin{tabular}{|l} 
KELEMAHAN(Weakneses ) \\
1. kurangnya sumber daya manusia \\
yang berkompeten di bidang \\
pemasaran \\
2. Kurangnya jumlah tenaga \\
pemasaran yang tersedia \\
3. $\begin{array}{l}\text { Kurangnya sumberdaya dibidang } \\
\text { jurnalis yang berkompeten }\end{array}$ \\
4. $\begin{array}{l}\text { Kurangnya Investor/sumber } \\
\text { dana yang kuat yang mampu } \\
\text { mengembangkan perusahaan }\end{array}$
\end{tabular} \\
\hline $\begin{array}{l}\text { PELUANG (Opportunities) } \\
\text { 1. Konsisten terhadap berita yang } \\
\text { mengusung jusnalis positif } \\
\text { 2. Dukungan royalitas dari } \\
\text { komunitas- komunitas } \\
\text { khususnya di wilayah Bogor } \\
\text { 3. Walaupun sumber daya } \\
\text { manusia yang kurang namun } \\
\text { masih banyak yang kreatif } \\
\text { dalam menyajikan program } \\
\text { yang menarik dan memakai } \\
\text { kombinasi banyak warna tajam } \\
\text { dalam surat kabarnya. } \\
\text { 4. Komunikasi persuasif yang } \\
\text { handal dan intentnya dalam } \\
\text { melakukan promosi personal } \\
\text { selling }\end{array}$ & 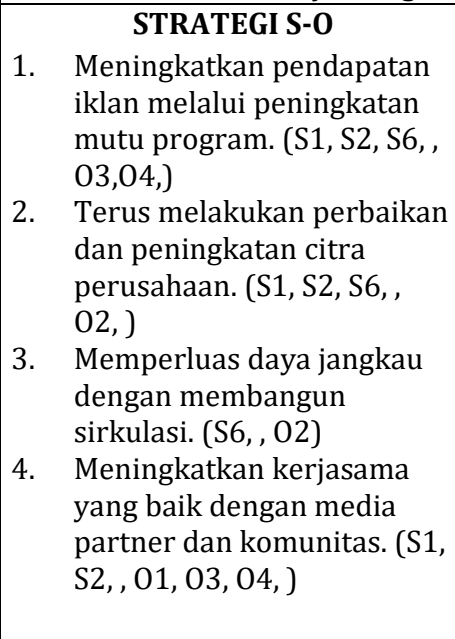 & $\begin{array}{l}\text { STRATEGI W-O } \\
\text { 1.Melakukan perekrutan tenaga kerja } \\
\text { muda. (W1,E2, W3, O2, O3) } \\
\text { 2.Melakukan strategi baru dalam } \\
\text { menayangkan program acara } \\
\text { reguler. (W2, W4, 04, ) } \\
\text { 3.Memperbaiki dan meningkatkan } \\
\text { komunitas pemirsa yang loyal. } \\
\text { (W2, W3, ) } \\
\text { Menayangkan acara dengan } \\
\text { kemasan yang menarik.(W2, , 02, } \\
\text { 03, ) } \\
\text { 5.Peningkatan mutu program/rubrik } \\
\text { yang telah ada. (W3, 01, 02, 04, ) }\end{array}$ \\
\hline \begin{tabular}{llr}
\multicolumn{3}{c}{ ANCAMAN( Threats) } \\
1 & $\begin{array}{l}\text { Kurangnya Investor dalam } \\
\text { pedanaaan } \\
\text { mempertahankan } \\
\text { eksistensian pelusahaan. }\end{array}$ \\
2 & $\begin{array}{l}\text { Sumberdaya manusia tidak } \\
\text { memadai. }\end{array}$ \\
3 & $\begin{array}{l}\text { Banyaknya surat kabar local } \\
\text { yang sudah lama berkembang }\end{array}$ \\
4 & $\begin{array}{l}\text { Terjadinya perang tarif iklan } \\
\text { dan perang kegiatan promosi }\end{array}$
\end{tabular} & 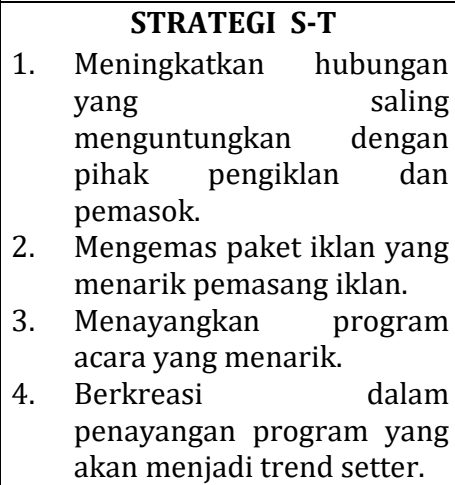 & 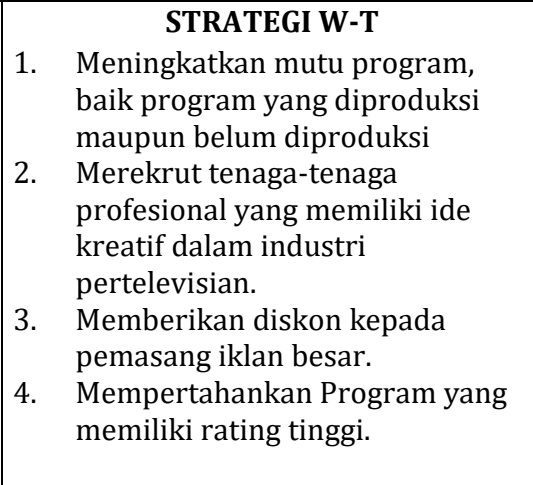 \\
\hline
\end{tabular}

Penentuan posisi perusahaan untuk mengatisispasi starategi pemasaran yang ada, maka peneliti membuat analisis total Skor faktor Internal dan eksternal matrik Rangkuti,2015 :

\section{Keterangan :}

a. Semua kategori masuk dalam kategori kekuatan, nilai mulai dari +1 sampai dengan +4 (sangat baik).

b. Setabilitas Lingkungan besar dibanding dengan rata-rata indrustri, nilainya adalah 1, sedangkan jika Stabilitas lingkungan perusahaan dibawah rata-rata industri nilai nya 4 
c. keunggulan semakin besar diberi +4 , jika keunggulan kecil, maka diberi rating +1

d. kekuatan semakin besar ratingnya,adalah 4 , jika nilai ancaman sedikit ratingnya 1

Tabel 2. Analisis dengan Menggunakan Matriks Space

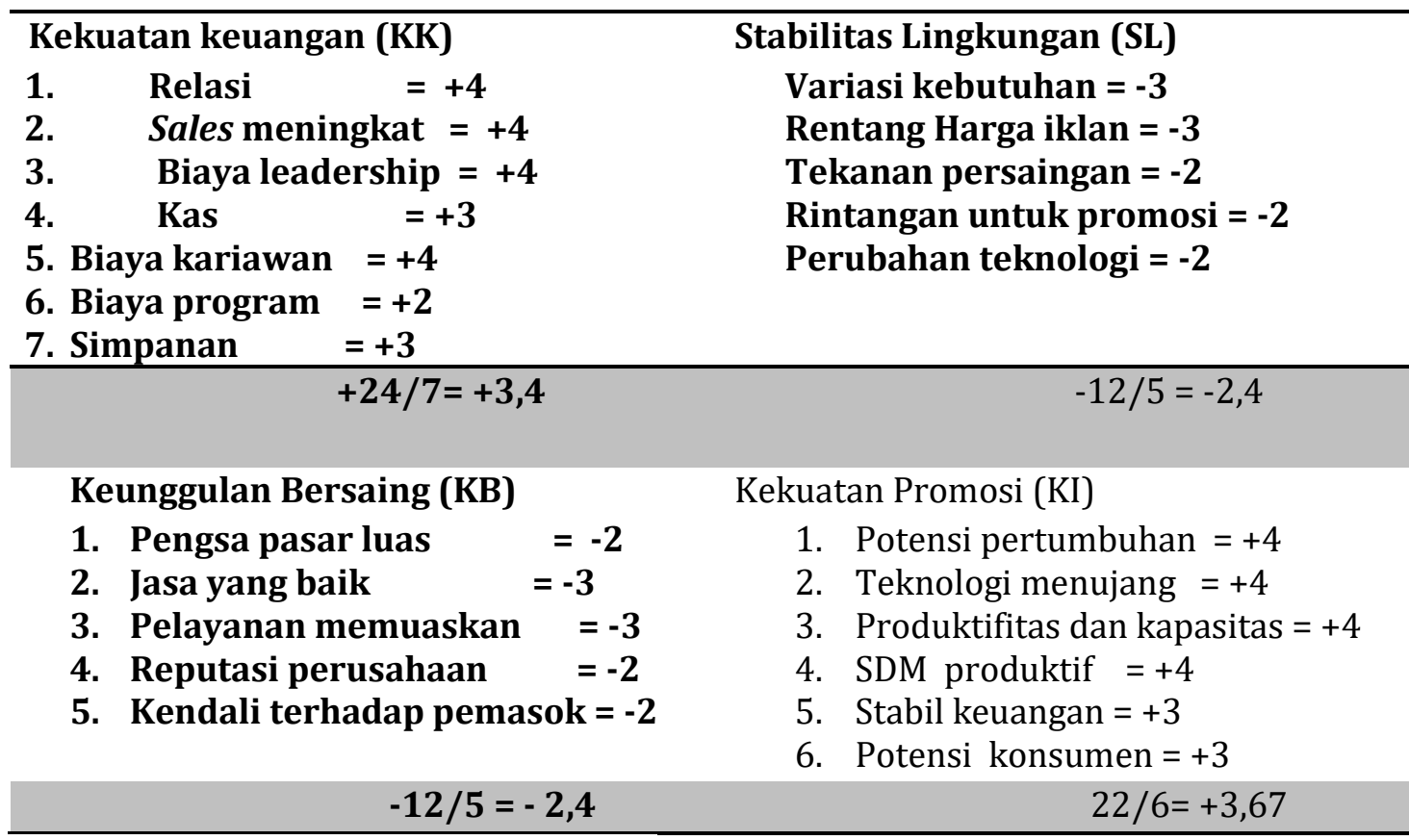

$$
\begin{aligned}
& \text { Analisis } \\
& \begin{aligned}
\text { Sumbu Vertikal (Sumbu Y) }= & \text { Kekuatan keuangan + Stabilitas Lingkungan } \\
& =+3,4-2,4=1 \\
\text { Sumbu Horizontol (Sumbu X) } & =\text { Kekuatan Promosi + Keunggulan bersaing } \\
= & +3,67-2,4=1,27
\end{aligned}
\end{aligned}
$$

Tabel 3. Hasil analisis matric Space

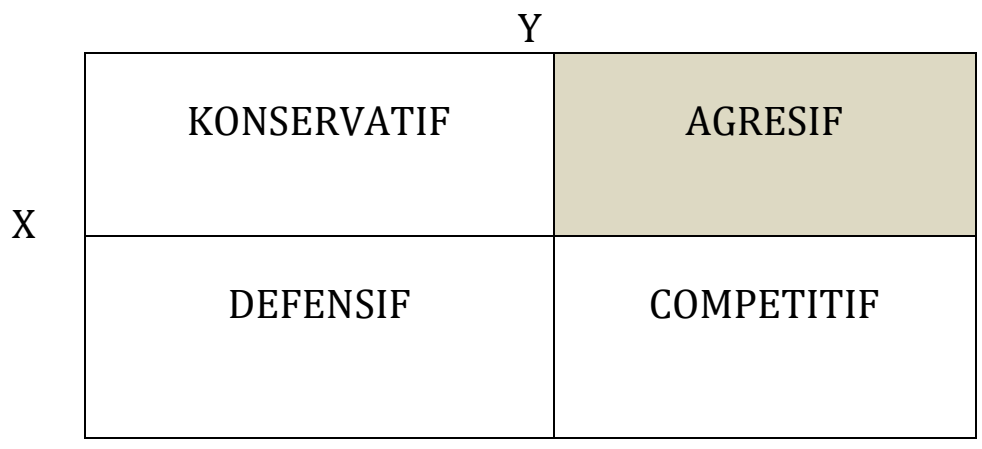

Hasil obaservasi lapang yang diperkuat dengan analisis SWOT MATRIX ditemukan berbagai alternatif strategi kekuatan dan 
peluang diantaranya yang paling memungkinkan untuk perkembangan perusahaan adalah strategi meningkatkan pendapatan iklan dengan komunikasi pemasaran melalui peningkatan mutu program, memperluas daya jangkau promosi personal selling dengan memperluas sirkulasi penyebaran surat kabar, menayangkan rubrik dengan kemasan desain gambar menarik, meningkatkan hubungan yang saling menguntungkan dengan pihak pemasang iklan, merekrut tenaga-tenaga profesional yang memiliki ide kreatif dalam industri media cetak. Berdasarkan observasi penulis melihat adanya ancaman terbesar surat kabar Bogor Today yaitu dengan tidak memilikinya Investor yang kuat namun karena didukung dengan konsistennya tenaga kerja jurnalis yang ada mampu konsisten terhadap berita yang positif yang dianggap menjadi kekuatan perusahaan dalam bidang penjualan surat kabar. Strategi berdasarkan pengolahan internal kekutan dan eksternal peluang memiliki beberapa kesamaan diantaranya adalah faktor penyusun utama yaitu mutu program yang berpengaruh dalam menentukan berhasil promosi.

Dengan menerapkan strategi baru dalam penayangan program rubrik yang telah ada, maka diharapkan untuk kedepanya pembaca tidak merasa jenuh dengan program regular tersebut. Untuk pembaca yang komitmen terhadap surat kabar Bogor Today diharapkan untuk tetap berlangganan dan bekerja sama dalam pemasang iklan. Seperti halnya suatu jasa yang akan mengalami penurunan setelah mencapai titik kejenuhan, maka diharuskan ada pembaharuan yang lebih kreatif dan innovatif dari tenaga kerja yang ada dalam surat kabar Bogor Today, sehingga masyarakat tetap memilih surat kabar Bogor Today sebagai surat kabar favorit pilihan pembaca. Jika dikaitkan dengan strategi promosi personal selling yang dipilih perusahaan, pertama adalah menayangkan program yang bermutu dan menarik untuk mendapatkan sebanyak mungkin pembaca untuk menjadikan kekuatan bagi promosi agar mencapai target pemasangan iklan. Disamping itu, untuk mempertahankan pangsa pembaca. sekaligus menjadi trend setter di dunia media cetak berusaha merumuskan strategi baru dalam penayangan program, baik dengan memperkuat program rubrik regular maupun menambah program /rubrik yang baru. Rentetan dari persaingan untuk belanja iklan merupakan pendapatan utama bagi industri media cetak.

Namun demikian dalam upaya meraih porsi dari belanja iklan, surat kabar Bogor Today juga harus berbagi dengan surat kabar lain yang sudah sejak lama beredar. Oleh karena itu, untuk langkah kedua surat kabar Bogor Today melakukan terobosanterobosan baru dalam meraih iklan. Langkah ketiga adalah melakukan efisiensi dan skala prioritas dalam pembiayaan. Peneliti menemukan dari hasil wawancara dengan A.M. 2016 bahwa Bogor Today memiliki perencanaan strategi promosi personal selling dengan teknik komunikasi persuasif jangka pendek, mempetatahankan kebijakan harga , mengedepankan pengendalian dan pengawasan yang ketat terhadap anacaman wartawan yang tidak bertanggung jawab, membina hubungan baik dengan para stakeholder dan konsumen untuk menstabilkan keeksistensian, mengadakan promosi seperti promo harga pasang iklan. Sementara program jangka panjang memanatau perkembangan teknologi, memahami serta mengontrol perkembangan media, terus menerus melakukan kerjasama dengan komunitas maupun perusahaan.

Jadi dengan perencanaan berikut, maka promosi personal selling surat kabar Bogor Today layak untuk dipertahankan walaupun banyaknya kelemahan internal dan ancaman eksternal namun dengan ini dapat ditanganu dengan faktor internal kekuatan dan eksternal peluang yang telah dijabarkan di atas maka kelemahan dan 
ancaman dapat ditangani dengan kekuatan dan peluang yang ada.

\section{KESIMPULAN DAN IMPLEMENTASI}

\section{Kesimpulan}

Dari hasil pembahasan pada bab sebelumnya dapat disimpulkan bahwa promosi personal selling Bogor Today layak untuk lanjutkan. Hal ini dilihat dari hasil Analisis SWOT yang cenderung agresif dengan indikator kekuatan dan peluang yang kuat baik untuk perusahaan dalam proses sebelumnya, proses komunikasi pemasaran dengan meggunakan promosi personal selling surat kabar Bogor Today, memakai pendekatan komunikasi persuasif, mampu membuktikan keunggulan yang dimiliki Bogor Today dengan mempengaruhi konsumen secara sadar dan terperinci akan jasa yang dimiliki rurat kabar Bogor Today.

Dalam pelaksanaanya promosi personal selling Surat Kabar Bogor Today berhasil dalam menarik minat konsumen memasang iklan dilihat dari beberapa narasumber yang telah berlangganan iklan surat kabar Bogor Today mengakui bahwa Bogor Today melakukan pertemuan langsung perusahan yang bekerja sama meliputi Perusahaan citrus Bogor, Universitas Djuanda, Komunitas Bogor Women club, Paguyuban Budi Asih, dengan ini konsumen mendapatkan fasilitas rubrik iklan yang bermanfaat mampu mengingatkan kembali kepada pembaca surat kabar Bogor Today akan produk/ jasa yang dimiliki dari kosumen yang memasang iklan surat kabar Bogor Today.

Proses personal selling Bogor Today mempunyai hambatan seperti kurangnya sumber daya manusia dan kurang solidnya tenaga kerja yang ada mempu memperhambat proses kemasuan surat kabar Bogor Today.

\section{Implementasi}

Saran yang diajukan dalam penelitian ini dilihat dari Analisis swot di bab sebelumnya bawa ancaman yang kuat adalah tidak tidukung dnegan sumber dana yang kuat sehingga tidak memfasilitasi Sumber Daya Manusia yang berkopeten, hal ini bisa dimenimalisir SDM yang ada ataupun dengan merekrut SDM telah lulus SMK atau perguruan tinggi ikut dalam pelatihan dalam perusahaan Bogor Today untuk menhasilkan tenaga-tenaga kerja yang baru yang mampu dianggap produktif. Dengan penanganan ini mampu menjadikan kineja baru yang berkompeten dan mampu terlibat untuk mengambangkan perusahaan Bogor Today dari segi pemberitaan, ataupun promosi personal selling menarik minat pemasang iklan.

\section{DAFTAR PUSTAKA}

Sukmayati D. 2013. Strategi komunikasi pemasaran harian Joglosemar dalam upaya menarim minat pemasang iklan periode februari- april 2013. Jurnal komunikasi. 1 (3) : 1-9.

Efendy OU. 2003. Ilmu komunikasi teori dan praktek. Bandung: Remaja rosdakarya.

Indrapraja RM. 2015. Strategi komunikasi pemasaran jungleland adventure theme park Bogor dalam upaya menarik pengunjung. Jurnal komunikatio. Bogor :Jurnal komunikatio. 1(1) : 1-7.

Kotler P. 1995. Menejemen Pemasaran, Analisis, Perencanaan, Implementasi, dan pengendalian (Ahli bahasa Ancella Anitawati Hermawan). Jakarta: Salemba Empat.

Munjani A. 2016. Hasil wawancara, Bogor Today. (Catatan Lapang Peneliti).

Prisgunanto I. 2006. Komunikasi Pemasaran (strategi dan teknik). Bogor : Ghalia Indonesia. 
Rangkuti F. 2015. Teknik membedah kasus bisnis Analisis SWOT. Jakarta: PT. Gramedia Pustaka Utama.

Spiro, Weitz. 1990. Personal selling Process. Journal of Bussines \& Industrial Marketing. XXVII. 61-9.

Sugiyono. 2012. Metode penelitian kualitatif dan kuantitatif dan $R \& D$. Bandung: Alfabeta.

Yuliani, Fina.2006. Analisis strategi promosi pemasaran terhadap peningkatan iklan PT. Indosiar visual MANDIRI, Tbk. Bogor: UT- Menejemen IPB. 
